\title{
On Producing the Alien Within: A Reply
}

\author{
Audrey Macklin
}

Shortly after the last contributor posted a comment on this Forum, reports of the Charlie Hebdo attacks erupted in the media. The assailants were two French brothers (Cherif and Siad Kouachi) who claimed affiliation to Al Qaeda in Yemen. Hours later, an associate (Amiday Coulibaly) killed a police officer, then rampaged through a kosher Hyper Cacher supermarket and murdered four hostages. All three men were slain two days later in confrontations with French police and security. That same day, the notorious 'Finsbury Mosque cleric', British national Abu Hamza, was sentenced to life in prison by a US court for terrorism related crimes. Most recently, the French Conseil Constitutionnel upheld a law permitting denaturalisation of dual-national French citizens convicted of terrorist offences. ${ }^{1}$ One cannot but wonder whether the Charlie Hebdo and Hyper Cacher attacks cast a long shadow over the Conseil Constitutionnel's deliberations, even though all three men were French by birth and therefore outside the purview of the denaturalisation law.

The horrific deeds of the French perpetrators struck at the heart of liberal democratic values: freedom of expression and religious tolerance. States understandably seek new and better tools to prevent future atrocities; the impulse toward retribution at such moments seems hard to resist. Do these attacks make the case for citizenship revocation? I remain sceptical that citizenship revocation advances the objective of protecting liberal democracies, or that pursuit of unalloyed retribution is an objective worthy of liberal democracies.

Defenders of citizenship stripping offer a mix of instrumental and noninstrumental justifications, but Kay Hailbronner, Christian Joppke and Peter Schuck lean toward the latter more than the former. Despite its rejection by

1 The law permits denaturalisation of dual nationals who commit terrorism offences within fifteen years of naturalisation ('Moroccan-born man jailed on terror charges to lose French nationality', The Guardian, 23 January 2015, available at http://www.theguardian.com/world/2015/jan/23/

moroccan-born-man-jailed-terror-lose-french-nationality-sahnouni)

(C) The Author(s) 2018

R. Bauböck (ed.), Debating Transformations of National Citizenship,

IMISCOE Research Series,

https://doi.org/10.1007/978-3-319-92719-0_45 
the US Supreme Court over fifty years ago, both Hailbronner and Joppke revert to the legal fiction of constructive renunciation and insist that certain conduct communicates an irrefutable intention of terrorists to renounce their own citizenship. Schuck revises the fiction by acknowledging that perpetrators may not actually wish to renounce citizenship, but then discounts an intention to maintain citizenship for 'tactical and cynical' purposes. But however attractive the fiction of constructive renunciation, it does not become truer with repetition, or with the passage of time, or by writing new characters into the narrative. Citizenship revocation for misconduct while a citizen is not chosen by the citizen; it is inflicted by the state.

Joppke explains that Germany would have been wrong to regard members of the RAF as menacing enough to warrant denationalisation, and I suspect he would also condemn the United States denaturalisation of Communist citizens in the twentieth century as hysterical overreaction. But he remains confident that one can transcend historic patterns of panicinduced political myopia and he thus arrives at the conclusion that Islamic terrorists are uniquely suitable for citizenship revocation. Peter Schuck contends that citizenship revocation, when employed judiciously against terrorists, strengthens the value of citizenship itself. Kay Hailbronner adds that my arguments do not address the illegality of citizenship revocation under international or constitutional law, but rather proceed from unarticulated notions of legitimacy and morality. Space does not permit a proper reply to the last criticism. Readers are invited to read my published article on citizenship revocation in the Queen's Law Journal, which addresses citizenship revocation for misconduct under international and constitutional law. ${ }^{2}$

Consider citizenship revocation in relation to the goal of bringing perpetrators to justice. As I mentioned in my kick-off text, fear of citizenship revocation is unlikely to deter those bent on martyrdom, and the deaths of the Kaouchi brothers and Coulibaly seem to demonstrate that. As for Abu Hamza, it is worth noting that the UK did attempt to strip him of citizenship. It was thwarted because deprivation would have rendered the Egyptian-born cleric stateless. But the fact that Abu Hamza remained in the UK as a UK citizen made him available for extradition to face charges in the United States, where he was tried, convicted and sentenced to life imprisonment for terrorism offences after an open and fair trial. Had he been stripped of UK

2 Macklin, A. (2014), 'Citizenship Revocation, the Privilege to Have Rights and the Production of the Alien', Queen's Law Journal 40 (1): 1-54. 
citizenship and expelled to Egypt, he would never have faced justice in a US court, or anywhere for that matter. ${ }^{3}$ I take the view that prosecution, trial and conviction are preferable responses to past acts. As for pre-empting incipient risks, various states have begun revoking passports of citizens allegedly bound for IS camps in Syria and Iraq. Restricting exit in this manner is only available in relation to citizens. Stripping citizenship permits states to shed their duty and responsibility toward nationals; it also deprives them of the authority to subject them to criminal prosecution and to thereby make a tangible contribution to bringing terrorists to justice under the rule of law.

Schuck, along with Hailbronner and Joppke, concede that existing practices of citizenship revocation breach basic norms of fairness. They regard these flaws as contingent defects that are severable from the abstract question of whether citizenship revocation for misconduct can be justified. I find the attempt to segregate theory from practice unconvincing in this context, and Matthew Gibney's intervention highlights the way in which attempts by the judiciary to hold the state to requirements of legality simply breed more tactics of state evasion. A chronic failure of a state practice to comply with fundamental norms of legality across time and space invites the inference that there is something about what the state is endeavouring to do that ineluctably and incorrigibly perverts the process of how it does it. ${ }^{4} \mathrm{~A}$ fair process leading to banishment, like a fair process culminating in the death penalty, can only ever operate as a mirage that legitimates on-going practices that will - inevitably and necessarily - fail to meet basic norms associated with the rule of law.

This leaves a defence of citizenship revocation that does not depend on practicality or utility, but instead rests on the insistence that revocation is just and fitting punishment of those who abuse the privilege of citizenship. I argue that when citizenship becomes revocable for misconduct, citizenship

3 Egypt does not extradite its nationals, and the Egyptian criminal justice system does not inspire confidence in its capacity to administer justice.

4 This point draws on the insight of legal theorist Lon Fuller. He admitted that his principles of legality were formal in the sense that they did not stipulate any substantive moral content to law. But he also maintained that legal systems that were intent enacting morally repugnant laws would be hard pressed to reconcile achievement of those objectives with compliance with principles of legality. I extend Fuller's intuition to suggest that a chronic pattern of noncompliance with principles of legality in relation to a particular law supports an intuition that the law is normatively defective in substance. 
as legal status is demoted from right to privilege. This is a specifically legal argument about the juridical fragility of a privilege compared to a right. Joppke's comment that citizenship in western states is a privilege because citizenship delivers so little to citizens of most non-western states is a nonsequitur. I may feel privileged to be a Canadian citizen and to benefit from the rights, entitlements and security of Canadian citizenship, but that does not make citizenship as such a privilege. And it would be peculiar indeed if only liberal democratic states that guarantee robust citizenship were entitled to revoke citizenship qua privilege, while poor and dysfunctional states that deliver only a meagre citizenship, were not so entitled. Schuck maintains that citizenship revocation, properly wielded, does not weaken citizenship, but can actually 'strengthen citizenship by reaffirming the conditions on which it is based.' I am not sure exactly what this means but his subsequent invocation of capital punishment does alert one to the rhetorical symmetry of his claim with similar assertions by death-penalty advocates: If one is convinced that the value of life is strengthened when the state executes a murderer, perhaps one will also be persuaded that citizenship is strengthened when the state denationalises a terrorist. The corollary also applies: If one is not attracted by the first proposition, perhaps one should resist being seduced by the second.

Jo Shaw's insightful intervention about the implications of denationalisation for EU citizenship brings to the discussion the important issue of proportionality, a matter Hailbronner also addresses briefly. Stepping back from the specificities of EU citizenship, a proportionality inquiry into citizenship deprivation directs us to the question of whether the state can achieve its objectives through less rights-infringing means than the impugned law. If one takes seriously the injunction against statelessness, the answer must surely be yes. However one frames the goals and purposes of citizenship deprivation, it remains true that states can and do deploy other means to address, contain and denounce threats to national security from mononationals. ${ }^{5}$ They must do so because denationalisation is not a legal option,

5 States can and do use the criminal law to prosecute people for terrorist related offences committed at home and abroad. Expanded police powers of investigation and surveillance enable detection. Passport confiscation that prevents travel to conflict zones restrains a right of citizenship (exit), and some states prosecute citizens who participation in combat abroad when the return. Some states also restrict the right of citizens abroad to re-enter in the name of national security. I consider this less defensible as a matter of law, both in relation to the excluded citizen and other affected states but cannot develop that argument here. 
yet no state will be heard to say that it is disabled from protecting the nation adequately because it cannot denationalise mono-citizens.

Schuck proclaims that a state is 'powerless to protect itself and its people from imminent, existential threats', if denied access to denationalisation as a weapon. Not only does this ignore the resources currently available to states, it dramatically overestimates what citizenship revocation would add to the arsenal. Unless a state could mount evidence showing that dual citizens pose a qualitatively different and graver threat to national security than mono-nationals, I doubt that citizenship revocation for some citizens (but not others) could survive a rigorous proportionality analysis. And by advancing revocation as a response to 'imminent, existential' threats, he defeats his own claim that the process of citizenship revocation can, in principle, abide by standards of procedural fairness. Fair processes take time, so whatever threat revocation purports to eliminate, it cannot be imminent. And is it really a good idea to dump an 'imminent, existential threat' on another state and its people anyway?

Rainer Bauböck correctly and helpfully reminds us that what is at issue is citizenship as legal status. Legal citizenship, as an institution that regulates membership within and between states, performs certain specific functions that have formal implications. Among liberal states, equality of status and security of that status are two defining features of legal citizenship. The former speaks to citizenship's internal dimension by ensuring that all citizens within a state are recognised and treated as equal to one another. The latter speaks to citizenship's external dimension. In functional terms, nationality not only protects individuals from what Michael Walzer calls the 'infinite precarity' of statelessness, it also serves an international system of sovereign states in ensuring that at least one mailing address is affixed to every individual for purposes of state responsibility and deportation.

Apart from Joppke, all contributors accept statelessness as a constraint on citizenship stripping. In the world as we know it, where all habitable space is already assigned to some state, the claim that a citizen, by virtue of his or her conduct, does not belong to this state must, therefore, entail the claim that the person does belong to that state. ${ }^{6}$ This exposes two related problems for conduct-based revocation. The first is that the people whom

6 One could, I suppose, imagine a world where states re-appropriate statelessness in order to resurrect the figure of the global legal outcast (hostis humani, or perhaps homo sacer). Stripped of law's protection, this global outlaw could be killed or punished with impunity. I will set this aside this possibility, and I am unsure if this is what Joppke has in mind. 
Joppke depicts as appropriate targets of denationalisation are not merely enemies of a particular state or government. On his view, they 'explicitly posit themselves outside the political community of the nation-state'. In other words, they repudiate citizenship as such or, if one prefers, pose as 'citizens' of a non-state entity that every other state in the world rightly regards as deeply threatening and inimical to their security. One expects that they will be as 'tactical and cynical' in their connection to one citizenship as to another. The Canadian citizenship revocation law validates this model of the global terrorist by making conviction for a terrorist-related offence in another country grounds for revoking Canadian citizenship. If another state regards a Canadian citizen as a terrorist, that is reason enough for Canada to conclude that his citizenship connection to Canada is inauthentic and warrants severance.

Joppke's own characterization of the terrorist's relationship to citizenship makes his argument about denationalisation self-defeating. If terrorists disavow citizenship as such, and are indeed hostis humani generi (enemies of all humanity), the same facts that would allow Joppke to pronounce that the Kouachis (for example) did not really belong to France must also yield the conclusion that they did not belong to any other state either. As a practical matter, if one state declares that formal possession of legal status is normatively insufficient to attach the terrorist to that state, it can hardly press the claim that legal status is sufficient to attach him to another state.

Joppke mocks Peter Spiro for making the sensible observation that neither al Qaeda nor Islamic State are states, which means that they are not deportation destinations. Hailbronner abets Joppke by musing about whether IS' military control over patches of land in the midst of violent conflict could be ratcheted up into something approximating statehood. If this is meant to hint at a viable legal option for where to dispose of otherwise stateless citizens, one might as well explore the equally plausible (from a legal perspective) option of launching them into space to orbit the globe aboard some inter-galactic Flying Dutchmen. ${ }^{7}$ Alternatively, perhaps we are meant to

7 It seems more likely that the UK will simply continue the practice of depriving citizens of their UK citizenship while abroad, now accompanied with a statement that the Home Secretary believes that target can obtain citizenship elsewhere. Even if the person does not, in fact, have access to another citizenship, the individual's physical location outside the UK and inside another state (to which they may have no legal relationship) will impose insuperable hurdles on challenging the decision or compelling the UK to repatriate him. 
shrug off as a convenient fact that powerful states can opportunistically denationalise their citizens while they are abroad in conflict zones. Even if they are rendered stateless, they become some other [failing] state's problem.

Bauböck's contribution directs one to another dimension of belonging, which reveals the second problem with Joppke's approach. Citizenship stripping's revival traces back to the anxiety about so-called 'home-grown' terrorists who, unlike the iconic foreign menace, actually possess citizenship by birth. Revoking citizenship enables the state to recast them as the alien within, in order to then cast them out. Denationalisation serves the narrative of terrorism as always and essentially foreign to the body politic by literally transforming the citizen-terrorist into the foreign outcast. But the very term 'home-grown' refutes the premise. The Kaouchi brothers were French citizens. They were orphaned as children and raised as wards of the French state. It is difficult to see them other than as products of French society. The ideology that seized them originated elsewhere, but their receptivity to it also directs one's attention inward. Indeed, any viable anti-terrorism strategy must attend carefully and critically to the local conditions that produce a descent into disaffection, hatred and violence - whether of the Islamist, neo-Nazi or any other variety. The French assailants may have been alienated from France, but there is no state to which they belonged more. $^{8}$

Ultimately, arguments about citizenship revocation turn on underlying conceptions of what citizenship is for, and expectations about what citizenship as legal status can achieve. Citizenship signifies membership, but beyond that general descriptor, citizenship inhabits multiple registers across many disciplines which are not reducible to or fully commensurate with one another. Citizenship as legal status is powerful because it carries the force of law, but also limited in what it can achieve for precisely the same reason. It is enabled and constrained because it is citizenship law and because it is citizenship law.

8 One might object that the sample set is too limited: After all, there are dual citizens (especially those who naturalised as adults) who might reasonably be understood as more connected to their country of origin. A short answer is that even if true, it would be a clear conflict of interest to let one state of citizenship make that determination. A fuller answer, which lies beyond the scope of this intervention, would explain why this type of calculus is inimical to the security that distinguishes citizenship from other statuses. 
States can and do use law to promote and endorse commitment, patriotism and active citizenship. They do it through public education, programmes for social inclusion, support and assistance, sponsorship of the arts and recreation, and other policies that build solidarity and encourage 'good citizenship'. These various spheres of public activity are enabled through legal frameworks, and so law plays an important role here. Citizenship law's chief constructive contribution lies in imposing (reasonable) requirements for naturalisation, such as residence and language acquisition, that genuinely facilitate integration and commitment to the national community.

The state must also be concerned about 'bad citizenship' and it falls to the criminal justice and national security regimes to address the most egregious conduct that endangers or harms the national community. To conclude that contemporary citizenship law is ill-suited to advancing punitive goals does not deny that some people are very bad citizens, or that law plays a crucial role in addressing that fact. It simply opposes the recruitment of citizenship law to punish bad citizens by demoting them to non-citizens. ${ }^{9} \mathrm{~A}$ man who attacks his mother may be a terrible son who deserves to be prosecuted for his crime, but it is not the job of family law to disclaim him as the son of his mother. Citizenship law is not criminal law. Nor is it national security law. Nor should it be rigged to operate as a trap door that shunts citizens to immigration law.

Accounting for citizenship status' specific legal character also guides us toward what law can (and cannot) achieve. A number of plausible accounts of citizenship's normative foundation circulate in political theory. They typically involve some idea of commitment or allegiance, whether to the state, the constitution, or democratic self-government. I do not here express a preference among them, but rather observe that they tend to focus on the internal relationship between state and citizen, and the grounds upon which the relationship may be properly said to have ruptured. They do not attend to the external dimension of legal citizenship, namely the role of nationality in stabilising the international filing system for humanity, and they do not

9 The various legal strategies currently in use to detect, deter, prevent and respond to terrorism can and do fail, sometimes tragically and spectacularly. Is this because states have not arrogated to themselves sufficient coercive powers, or do inadequate human, technical and financial resources explain more about operational failure? 
furnish a satisfactory normative explanation for why the 'bad citizen' should be assigned to another state.

Citizenship law cannot subject to legal regulation the myriad values, practices and aspirations ascribed to citizenship-as-belonging. This is unsurprising: Citizenship status enfranchises citizens above the age of majority, but there is no legal compulsion to vote (except in Australia, Belgium, Brazil and a few other states) and citizenship law does not purport to penalise those who never exercise their right or duty of active citizenship. Nor does citizenship law purport to regulate access to most types of civil and social citizenship (in Marshallian terms), and I suspect most commentators agree that that is a good thing.

Nevertheless, defenders of revocation insist that citizenship law can and should regulate 'loyalty and allegiance' of citizens. The criminal law can punish people for intentionally committing wrongful acts, including treason, murder, and all other forms of horrific violence that concern us here. Some assailants may openly express contempt for their country of citizenship, while others (like the Ottawa shooter Joppke cites) display a messy history of mental illness, drug addiction and petty criminality preceding recent conversion to Islam. The putative value added by citizenship revocation is precisely that it makes lack of allegiance and loyalty the central element in defining crimes against citizenship. But to paraphrase Aldous Huxley, loyalty and allegiance are like happiness. They are by-products of other activities. Fostering love of country is a valid aspiration of states and worth cultivating. But it cannot be manufactured by the carrot of a citizenship oath (as Joppke has elsewhere ${ }^{10}$ acknowledged), nor will it be conjured by the stick of revocation. Law is not adept at producing sentiment on command.

Space constraints have led me to focus on those submissions that directly challenge my own position, and I have not responded to the cogent, provocative and creative insights offered by so many contributors. My own thinking has been deepened and challenged by them, for which I express gratitude and appreciation. I admit that I took as my remit citizenship revocation only in the literal, legal sense. I also acknowledge the criticism that

10 Bauböck, R. \& Joppke, C. (2010), 'How liberal are citizenship tests?', Robert Schuman Centre for Advanced Studies, EUDO Citizenship Observatory Working Paper No. 2010/41, Florence: European University Institute, available at http://cadmus.eui.eu/handle/1814/13956 
confining my focus to citizenship revocation does not pay due regard to the compelling claim, for example, that deportation of non-citizens may also constitute banishment in some circumstances, with attendant human rights implications. I hope that nothing I have said here gives the appearance of foreclosing or prejudging broader or different conceptions of banishment. There is always more to be said, and much to be done.

Open Access This chapter is licensed under the terms of the Creative Commons Attribution 4.0 International License (http://creativecommons.org/licenses/by/4.0/), which permits use, sharing, adaptation, distribution and reproduction in any medium or format, as long as you give appropriate credit to the original author(s) and the source, provide a link to the Creative Commons license and indicate if changes were made.

The images or other third party material in this chapter are included in the chapter's Creative Commons license, unless indicated otherwise in a credit line to the material. If material is not included in the chapter's Creative Commons license and your intended use is not permitted by statutory regulation or exceeds the permitted use, you will need to obtain permission directly from the copyright holder.

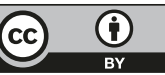

